\title{
Gut content analysis confirms the feeding plasticity of a generalist fish species in a tropical river
}

\author{
Análise do conteúdo estomacal confirma a plasticidade alimentar de uma espécie de \\ peixe generalista em um rio tropical
}

\section{Igor David Costa ${ }^{1,2 *}$ (D) and Ronaldo Angelini ${ }^{3}$}

${ }^{1}$ Instituto do Noroeste Fluminense de Educação Superior, Universidade Federal Fluminense - UFF, Av. João Jasbick, s/n, Bairro Aeroporto, CEP 28470-000, Santo Antônio de Pádua, RJ, Brasil

${ }^{2}$ Mestrado Profissional em Gestão e Regulação de Recursos Hídricos - PROFÁGUA, Universidade Federal de Rondônia - UNIR, Campus Ji-Paraná, Rua Rio Amazonas, 351, Jardim dos Migrantes, CEP 76900-726, Ji-Paraná, RO, Brasil

${ }^{3}$ Departamento de Engenharia Civil, Centro de Tecnologia, Universidade Federal do Rio Grande do Norte - UFRN, Campus Universitário, CEP 59072-970, Natal, RN, Brasil

*e-mail: igorbiologia@yahoo.com.br

Cite as: Costa, I.D. and Angelini, R. Gut content analysis confirms the feeding plasticity of a generalist fish species in a tropical river. Acta Limnologica Brasiliensia, 2020, vol. 32, e21.

Abstract: Aim: In this paper, we compared the diet composition of the South American silver croaker, Plasgioscion squamosissimus in preserved and impacted areas (agrarian land use) of an Amazonian river. Our objective was to quantify the plasticity in diet across different habitats and evaluate the importance of a carnivorous generalist species as an environmental indicator based on its feeding variation. Methods: We analysed the stomach contents of 135 individuals and compared the trophic level of P. squamosissimus and the source of ingested food items in the impacted and non-impacted habitats. Results: The trophic level values in both areas were similar. In both areas, P. squamosissimus used a wide variety of food items, consuming mainly fish and invertebrates of autochthonous origin. However, in terms of composition of food items, small pelagic fish and autochthonous items were more frequently consumed in the preserved area, while in the impacted area fish and benthic invertebrates were predominant in the diet. Conclusions: Our gut analysis suggests plasticity in P. squamosissimus diet across varying areas, which point to the ability of P. squamosissimus to modify their diet in the impacted situation, utilizing more benthic material on impacted area in order to maintain a similar trophic position.

Keywords: carnivorous; diet plasticity; trophic ecology; diet composition; Machado River (Brazil).

Resumo: Objetivo: Neste artigo, comparamos a composição da dieta da pescada branca Plasgioscion squamosissimus em áreas preservadas e impactadas (área agrária) de um rio amazônico, a fim de quantificar a plasticidade trófica em diferentes habitats e avaliar a importância de uma espécie carnívora generalista como um indicador ambiental baseado em sua variação alimentar. Métodos: Analisamos o conteúdo estomacal de 135 indivíduos e comparamos o nível trófico de P. squamosissimus e a origem dos itens alimentares nos habitats impactados e preservados. Resultados: Os valores do nível trófico em ambas as áreas foram semelhantes. Nas duas áreas, P. squamosissimus utilizou uma grande variedade de itens alimentares, consumindo principalmente peixes e invertebrados de origem autóctone. No entanto, em relação à composição dos itens alimentares, pequenos peixes pelágicos e itens autóctones foram consumidos com maior frequência na área preservada, enquanto na área impactada predominaram os peixes e invertebrados bentônicos na dieta. Conclusóes: Nossa análise 
intestinal sugere a plasticidade na dieta de P. squamosissimus em diferentes áreas, sendo útil apontar a capacidade de P. squamosissimus de modificar sua dieta na situação impactada, utilizando mais material bentônico na área impactada, a fim de manter uma posição trófica semelhante.

Palavras-chave: carnívoro; plasticidade alimentar; ecologia trófica; composição da dieta; rio Machado (Brasil).

\section{Introduction}

Deforestation is one of the major impacts in the tropical forest, affecting terrestrial and aquatic environments, changing the relations among organisms (Lorion \& Kennedy, 2009; Frederico et al., 2016) and the structure and composition of aquatic communities (Schneider \& Winemiller, 2008; Carvalho \& Tejerina-Garro, 2015). In this modified scenario, species' ability to change the use of preferred food items is key for determining which species will remain in the ecosystems (Zeni et al., 2019).

Many species characteristics could influence their ability to change diet in new habitat conditions, as body size (Van der Lee \& Koops, 2015), dispersal mechanisms (Gubiani et al., 2007), and feeding behavior (Bornatowski et al., 2014). Accordingly, generalist species have a large dietary breadth and can restructure food webs affected by different environmental impacts (Bartley et al., 2019).

Modifications in fish diets can be caused by spatial, seasonal and human changes in habitats, which influence abiotic conditions (e.g. oxygen concentration, temperature, $\mathrm{pH}$ ) and food availability (Whitehouse et al., 2017). Generalist carnivorous species have large feeding spectrum, consuming different food resources that are appropriate for their morphology, feeding behavior and digestive capacity (Bennemann et al., 2011; Neves et al., 2015).

Fish diets may also be influenced by the interface between land and river (riparian zone) in a watershed and are important for the exchange of organic matter between terrestrial and aquatic ecosystems (Pusey \& Arthington, 2003; Manna et al., 2012; Casatti et al., 2012; Zeni \& Casatti, 2014). Allochthonous organic matter, such as leaves and branches, are consumed directly by benthic macroinvertebrates (Rosi-Marshall et al., 2016) and serves as substrate for the development of microorganisms that are consumed by aquatic invertebrates and fish (Ferreira et al., 2012).

Most teleost fishes in tropical rivers have notable versatility in their feeding habits (Moyle \& Cech, 2004), which is a remarkable aspect of tropical rivers (Lowe-McConnell, 1999; Correa
\& Winemiller, 2014). The South American silver croaker, Plagioscion squamosissimus (Heckel, 1840), is a sedentary fish native to the Amazonian region (Santos et al., 2006) and is considered a valuable resource for human consumption and recreational fishing (Barros et al., 2012). In several environments and biomes (Hahn et al., 1999; Bennemann et al., 2000, 2006; Santos et al., 2016), P. squamosissimus is considered piscivorous (e.g. large rivers) (Hahn et al., 1997) or generalist carnivore (e.g. reservoirs) (Rocha et al., 2015). Due to its wide geographical distribution, abundance and tolerance to environmental stress in dammed river systems, P. squamosissimus could help as aquatic bioindicators in tropical and subtropical aquatic environments (Wunderlich et al., 2015).

To estimate the trophic position of this species, gut content analysis remains a useful method in order to comprehend the qualitative and quantitative diet of fish species, providing indicators of feeding habits (Baker et al., 2014). In this article, we hypothesized that there are differences in food resources consumed by Plagioscium squamosissimus (a predator) between a protected area (Biological Reserve of Jaru) and an unprotected area of the Machado River (Amazon Forest), reflecting trophic interactions in both food chains.

\section{Material and Methods}

\subsection{Study area}

The study was carried out in the Machado River (commonly referred to as Ji-Paraná River) basin, which covers $75,400 \mathrm{~km}^{2}$ in the State of Rondônia, Brazil (Figure 1 and 2).

This seventh-order river annually drains about $700 \mathrm{~m}^{3} \cdot \mathrm{s}^{-1}$ into the middle course of the Madeira River (Krusche et al., 2005). The Machado River has large individual rocks, rocky portions, as well as trunks and branches observed during the low water period with low sediment loads, typifying it as a clear-water Amazonian river (Goulding et al., 2003). The Machado River runs through the Jaru Biological Reserve (ReBio Jaru, Figure 1), which has a total area of $47,733 \mathrm{~km}^{2}$ (Brasil, 2010), with preserved riparian zone covered by ombrophylous 


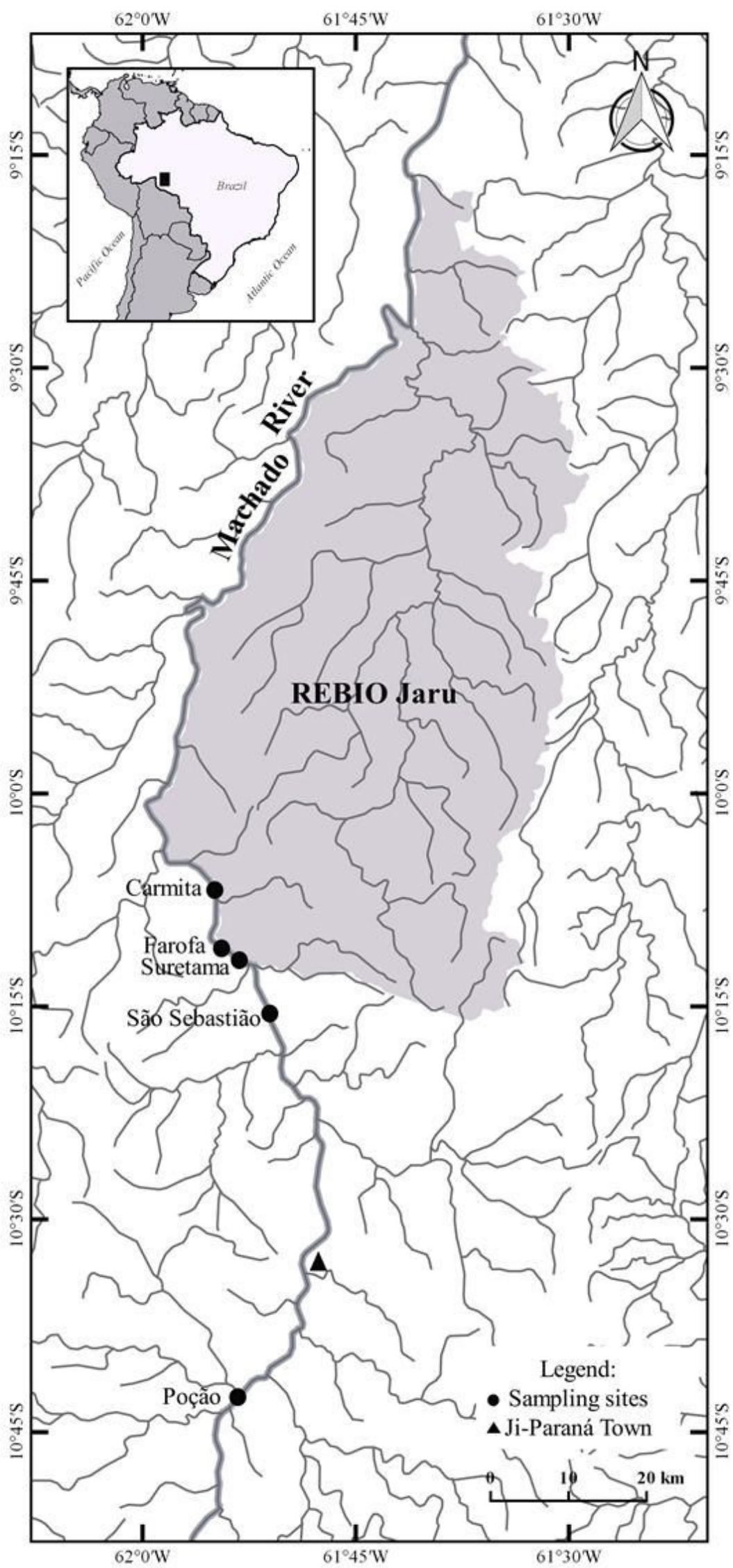

Figure 1. Machado River and sampling sites (See details in Figure 2), Rondônia State = black square, Brazil. 
forest that is mainly open and has low floristic variations (IBGE, 1992).

The preserved area has a riverine zone constituted of shrubby and woody angiosperms that establish a primary forest (2c), which could be considered reproduction hotspot and feeding for fish species, where fishing is prohibited (ICMBIO, 2010). The impacted area (poção site $=-50 \mathrm{~km}$ and Sáo Sebastião site $=-5 \mathrm{~km}$ upstream of the ReBio Jaru) is composed of pasture, with a riverine zone on the right bank composed of grasses, and a narrow strip with a few woody angiosperms and stretches of bare bushes on the left bank (Figure 2f). In this area there is constant sand dredging (Figure 2e) and fishing activities (artisanal and recreational; Figure 2d).

\subsection{Fish sampling}

Samplings were performed bimonthly from June 2013 to March 2015 at five locations, three within the preserved area in ReBio Jaru (Carmita, Farofa and Suretama), and two (São Sebastião and Poção) in the impacted area (Figure 1).

Eight sets of gillnets $(2 \times 20 \mathrm{~m}$ with mesh sizes varying from 30 to $100 \mathrm{~mm}$ ) were used. Sampling effort was standardized, and scientific fishing was carried out for 24 hours continuously at each sampling site. A specimen was fixed in $10 \%$ formalin and preserved in $70 \%$ ethanol. Subsequently, this specimen was deposited in the Ichthyology collection at the Universidade Federal de Rondônia (voucher specimens: UFRO-ICT 023107).

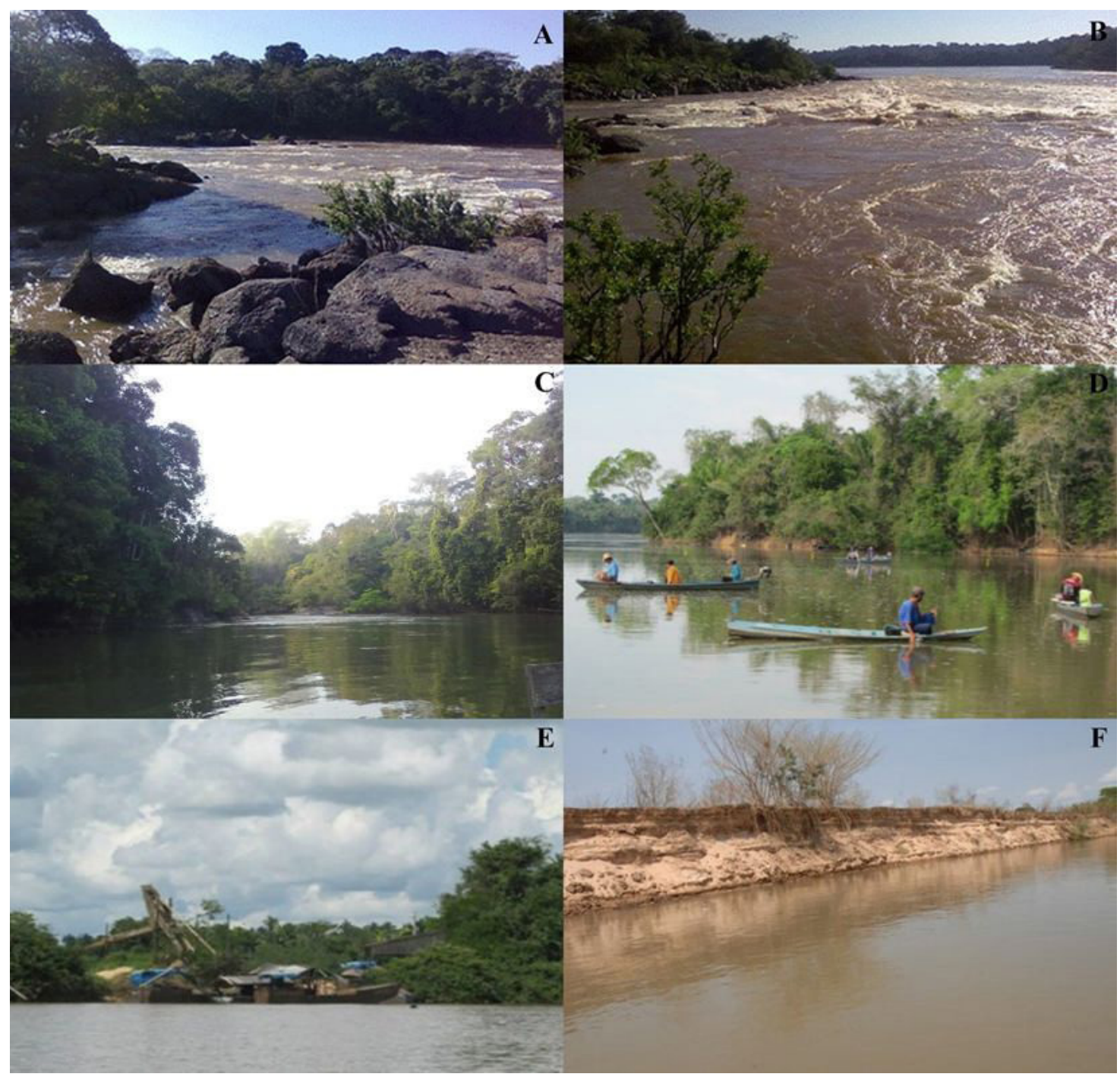

Figure 2. Sampling sites in the Machado River Basin, Rondônia, Brazil: (A) Carmita; (B) Farofa; (C) Suretama (preserved area); (D) São Sebastião, fishing activities; (E) sand dredging activity; and (F) Poção, pasture, few woody angiosperms and stretches of bare bushes, degraded local banks and (impacted area). 


\subsection{Diet analysis}

The abdominal cavities of 135 specimens were opened, and their stomachs were removed. Then, gut contents were stored in $70 \%$ alcohol, and food items were analyzed and identified to the lowest taxonomic level (Hamada \& Ferreira-Keppler, 2012; Hamada et al., 2014). The occurrence frequency $(\mathrm{Fi} \%)$ and the method of volumetric frequency $(\mathrm{Vi} \%)$ were used to quantify the gut contents (Hyslop, 1980). The occurrence frequency method, is the number of stomachs a diet item is found in divided by total stomachs containing food. The stomachs with no food were used for the Fullness index (FI) calculations and later discarded. For the volumetric frequency, the volume of each item was obtained using the percentage in relation to the total value of all gut contents. The volume was obtained using a gridded dish, and cubic millimeters were converted to milliliter (Hellawell \& Abel, 1971). All values were combined in a feeding index (IA $i)$, given by Equation 1:

$$
I A i=(F i x V i) / \Sigma(F i x V i) \times 100
$$

where $i=1,2, \ldots \mathrm{n}$ food items; $\mathrm{F} i=$ Frequency of occurrence of food item $i$; and $V i=$ Volume of food item I, proposed by Kawakami \& Vazzoler (1980).

Food items were grouped according to type (animal or plant) and origin (autochthonous or allochthonous). The FI was determined according to Hahn et al. (1999) and gut contents were coded as follows: 0 (empty), 1 (volume < 25\%), $2(25 \%<$ volume $<75 \%)$ and $3(75 \%<$ volume $<100 \%)$.

The trophic level (TL) of P. squamosissimus was calculated using the formula $\mathrm{TL}=1+$ (weighed average of TL's of each prey) (Pauly \& Christensen, 1995). Trophic level and maximum length of P. squamosissimus fish prey were determined using FishBase platform (Froese \& Pauly, 2019) and SeaLifeBase (2018).

\subsection{Data analysis}

In all analyzed individuals, the standard length $\left(L_{\mathrm{S}}\right.$ in $\left.\mathrm{cm}\right)$ was measured. The Shapiro-Wilk test of normality and Levene's test of homoscedasticity were used to determine whether parametric $t$-test or non-parametric Mann-Whitney U test should be used to test for differences in the $L_{\mathrm{S}}$ between preserved habitat and area impacted.

Chi-squared $(\chi 2)$ tests were applied to a contingency table (Zar, 1999) in order to verify the association between the absolute frequency of FI class in each study area. To compare areas, $\chi 2$ tests were applied between food origin (allochthonous or autochthonous), food type (plant or animal), and trophic level (TL) values. A non-metric multidimensional scaling analysis (nMDS) was used to examine multidimensional spatial variation in diet using the total volume of each item. The dissimilarity matrix used in the ordination was built using the Bray-Curtis index, which was performed in the software PAST (version 2.1.7 Hammer et al., 2001). Statistical tests were performed using $\mathrm{R}$ software, version 3.5.2 (R Development Core Team, 2018) and the packages vegan for parametric test $t$ or non-parametric Mann-Whitney $U$ test and $\chi 2$.

\section{Results}

A total of 135 specimens were analyzed: 75 were collected in the preserved area and 60 in the impacted area. The mean $L_{\mathrm{S}}$ in the preserved area $\left(L_{\mathrm{S}}=49.1 \pm 5.3 \mathrm{~cm}\right)$ was greater than that of the impacted area $\left(L_{\mathrm{S}}=44.2 \pm 8.3 \mathrm{~cm}\right)$ ( $\mathrm{U}$ Mann-Whitney, $\mathrm{U}=83.5 ; p=0.01$; $\mathrm{df}=1$ ). The Fullness Index (FI) did not differ significantly between preserved and impacted sites (Table 1).

Plasgioscion squamosissimus ingested a wide variety of food items as fish, shrimps, terrestrial and aquatic insects, as well as plant (Table 2). Astyanax bimaculatus (Linnaeus, 1758) was the most important food item in the preserved area, as well as unidentified fish fragments and terrestrial insects (Table 2, Figure 3a).

Compared to the preserved area, Pimelodus blochii Valenciennes, 1840 was the most important food item in the impacted area, as well as the shrimp, Tenellus trimaculatus (Boulenger, 1898) and Hypostomus plecostumus (Linnaeus, 1758) (Table 2, Figure 3b).

In both areas, $P$. squamosissimus showed similar trophic level values (mean of TL $\mathrm{preserved}=3.42 ; \mathrm{TL}_{\text {impacted }}$ $=3.62 ; \chi 2=0.0 ; p=0.95 ; \mathrm{df}=1)$. However, there was higher consumption of autochthonous material $(\chi 2=$

Table 1. Absolute frequency of Fullness Index (FI) class for gut content of $P$. squamosissimus.

\begin{tabular}{ccc}
\hline \multirow{2}{*}{ I } & \multicolumn{2}{c}{ Absolute frequency } \\
\cline { 2 - 3 } & Preserved area & Impacted area \\
\hline 0 & 43 & 36 \\
1 & 23 & 17 \\
2 & 4 & 4 \\
3 & 5 & 3 \\
Total & 75 & 60 \\
\hline
\end{tabular}

FI = 0: empty; FI = 1: <25\%; FI =2: between $25 \%$ and $75 \%$ and FI $=3$ : between $75 \%$ and $100 \%$. Samplings made at the Machado River, Brazil (June 2013 to March 2015). Contingency table $(\chi 2=1.40, p=0.06, \mathrm{df}=3)$. 
Table 2. Trophic level (TL), occurrence frequency ( $\mathrm{F} i \%)$, volumetric frequency $(\mathrm{V} i \%)$, and feeding index (IAi) for diet items from P. squamosissimus at preserved area and impacted area of Machado River, Brazil (June 2013 to March 2015). Item relevance ranking, based on $I A i$, was tested using $\chi 2$.

\begin{tabular}{|c|c|c|c|c|c|c|c|c|}
\hline \multirow{2}{*}{ Food items } & \multirow{2}{*}{ TL } & \multicolumn{3}{|c|}{ Preserved Area } & \multicolumn{3}{|c|}{ Impacted area } & \multirow{2}{*}{$\frac{\text { Item relevance }}{\text { by area }(p<0.01)}$} \\
\hline & & Fi\% & Vi\% & IAi & Fi\% & $\mathrm{V} i \%$ & $\mathbf{I A I}$ & \\
\hline \multicolumn{9}{|l|}{ Animal origin } \\
\hline Pimelodus blochii & 3.2 & 1.88 & 1.43 & 0.01 & 31.2 & 30.21 & 6.22 & $1^{\text {st }}$ impacted \\
\hline Astyanax bimaculatus & 2.5 & 18.75 & 15.01 & 1.81 & 15 & 2.5 & 0.22 & $1^{\text {st }}$ preserved \\
\hline Pterygoplichthys pardalis & 2 & 9.43 & 7.19 & 0.04 & & & & \\
\hline Serrasalmus rhomabeus & 4 & 1.88 & 1.43 & 0.01 & & & & \\
\hline Moenkhausia lepidura & 3.2 & 1.88 & 4.31 & 0.01 & & & & \\
\hline Hypostomus plecostumus & 2 & & & & 18.75 & 9 & 0.23 & \\
\hline Tenellus trimaculatus & 2.8 & & & & 6.96 & 5 & 0.25 & $3^{\text {rd }}$ impacted \\
\hline Sternopygus macrurus & 3.2 & & & & 12.5 & 3 & 0.07 & \\
\hline Fish no identified & 2.9 & 24.5 & 29.3 & 0.5 & 18.75 & 10.13 & 0.17 & $2^{\text {nd }}$ preserved \\
\hline Scales & 2.9 & 7.54 & 5.03 & 0.01 & 12.5 & 5 & 0.07 & \\
\hline Aquatic insects & 2 & 15 & 15.8 & 0.16 & 12.5 & 5 & 0.15 & \\
\hline Terrestrial insects & 2 & 7.54 & 10 & 0.34 & 6.25 & 3 & 0.02 & $3^{\text {rd }}$ preserved \\
\hline Nematodes & 2 & 5.6 & 4.31 & 0.01 & & & & \\
\hline Shrimp & 2 & & & & 6.25 & 2.56 & 0.32 & $2^{\text {nd }}$ impacted \\
\hline \multicolumn{9}{|l|}{ Vegetal origin } \\
\hline Plant no identified & 1 & 5.66 & 4.31 & 0.01 & & & & \\
\hline Leaves & 1 & 3.77 & 2.87 & 0.01 & & & & \\
\hline
\end{tabular}
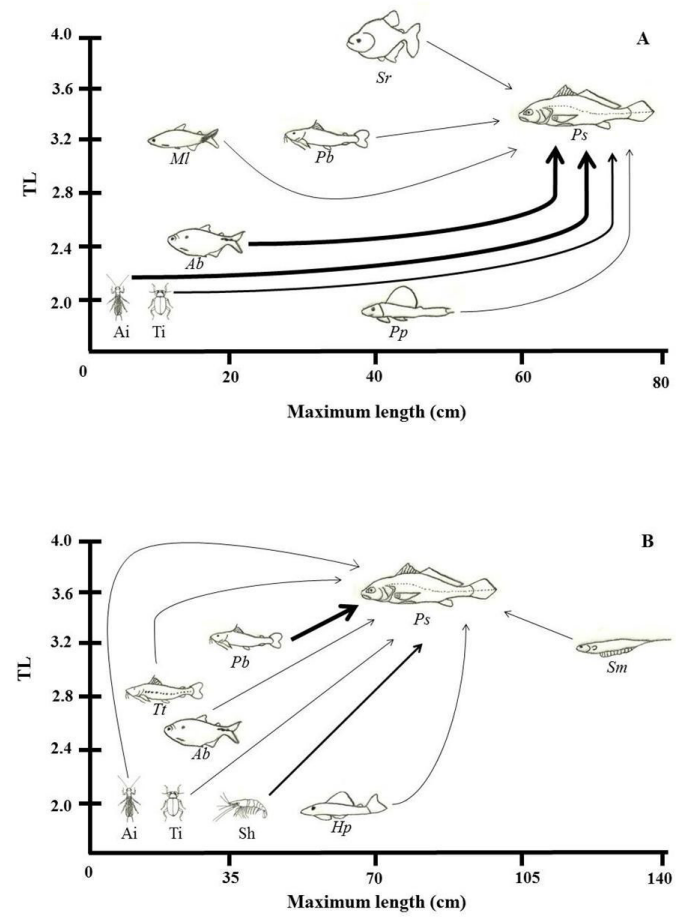

Figure 3. Simplified food chain for Plagioscium squamosissimus $\left(P_{s}\right)$ in preserved area $(\mathrm{A})$ and impacted area (B) in Machado River (Brazil). Arrow width illustrates importance in the diet $\mathrm{Y}$-axis = trophic level (TL), X-axis: maximum length $(\mathrm{cm})$. (TL and maximum length are from Froese \& Pauly, 2019 and or literature). $P s=$ Plasgioscion squamosissimus; $\mathrm{Sr}=$ Serrasalmus rhombeus; $M l=$ Moenkhausia lepidura $P b=$ Pimelodus blochii; Ab = Astyanax bimaculatus; Pp = Pterygoplichthys pardalis; $S m=$ Sternopygus macrurus; $T t=$ Tenellus trimaculatus; $H p=$ Hypostomus plecostumus; $\mathrm{Sh}=$ Shrimp; $\mathrm{Ai}=$ Aquatic insect; and $\mathrm{Ti}=$ Terrestrial insect.

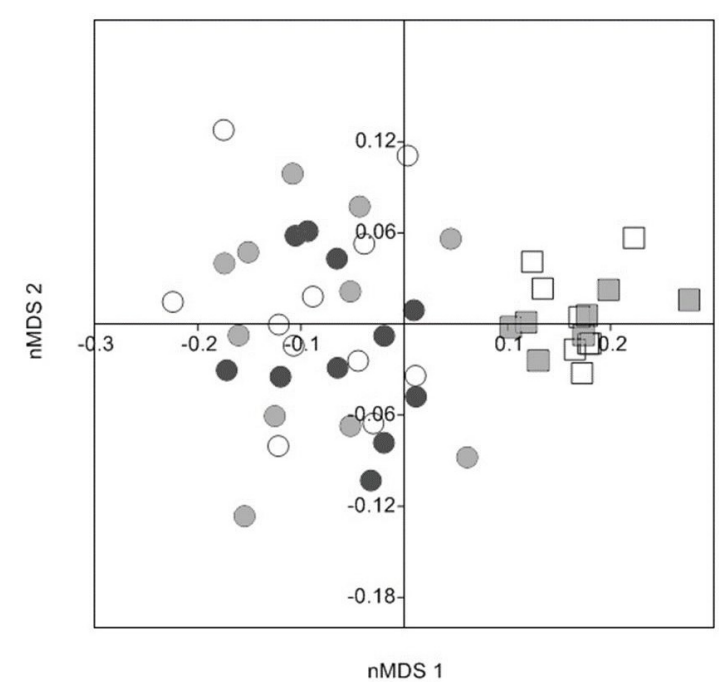

Figure 4. Non-metric multidimensional scaling analysis (nMDS) of volumetric data of the gut contents of P. squamosissimus in preserved area (circle) and impacted area (square), in Machado River (Brazilian Amazon), from June 2013 to March 2015. Carmita (dark gray circle), Farofa, (light gray circle), Suretama (white circle); São Sebastião (light gray square) and Poção (white square).

12.1; $\mathrm{p}<0.05 ; \mathrm{df}=1)$ and animal items $(\chi 2=12.6$, $\mathrm{p}<0.05, \mathrm{df}=1)$ in the preserved area.

In the NMDS analysis, clustering was observed based on the distinct use of food resources with a "stress" of 0.11 (Figure 4).

The food items that showed higher volumetric frequency in the gut contents of $P$. squamosissimus in the preserved area were non-identifiable fish 
(29.3\%), followed by aquatic insects (15.8\%) and A. bimaculatus (15.0\%). For the impacted area, P. blochii (30.2\%), followed by non-identifiable fish (10.1\%) and H. plecostumus (9.0\%) were the most representative (Figure 5).
There was no considerable overlap of items from animal (stress $=0.11$; Figure 6a), plant (stress $=0.08$; Figure $6 b$ ), autochthonous (stress $=0.20$; Figure $6 \mathrm{c}$ ), and allochthonous origin (stress $=0.23$; Figure $6 \mathrm{~d}$ ) consumed by $P$. squamosissimus in each area.

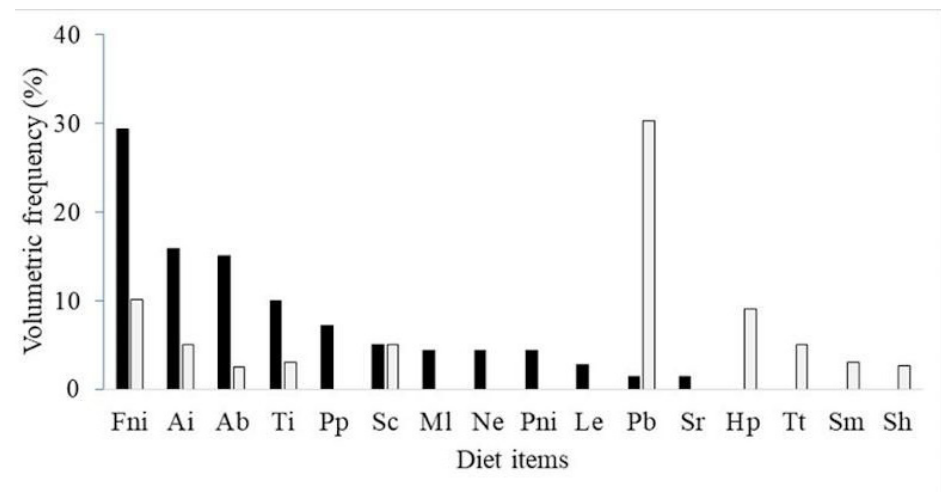

Figure 5. Volumetric data (\%) of the gut contents of P. squamosissimus in preserved area (black bar) and impacted area (gray bar), in Machado River (Brazilian Amazon), from June 2013 to March 2015. Fni = Fish no identified; $\mathrm{Ai}=$ Aquatic insects; $\mathrm{Ab}=$ A. bimaculatus $; \mathrm{Ti}=$ Terrestrial insects; $\mathrm{Pp}=P$. pardalis $; \mathrm{Sc}=\mathrm{Scales} ; \mathrm{Ml}=$ M. lepidura $;$ $\mathrm{Ne}=$ Nematodes; $\mathrm{Pni}=$ Plant no identified; Le $=$ Leaves; $\mathrm{Pb}=$ P. blochii $; \mathrm{Sr}=$ S. rhomabeus $; \mathrm{Hp}=$ H. plecostumus; $\mathrm{Tt}=$ T. trimaculatus; $\mathrm{Sm}=$ S. macrurus $; \mathrm{Sh}=$ Shrimp.
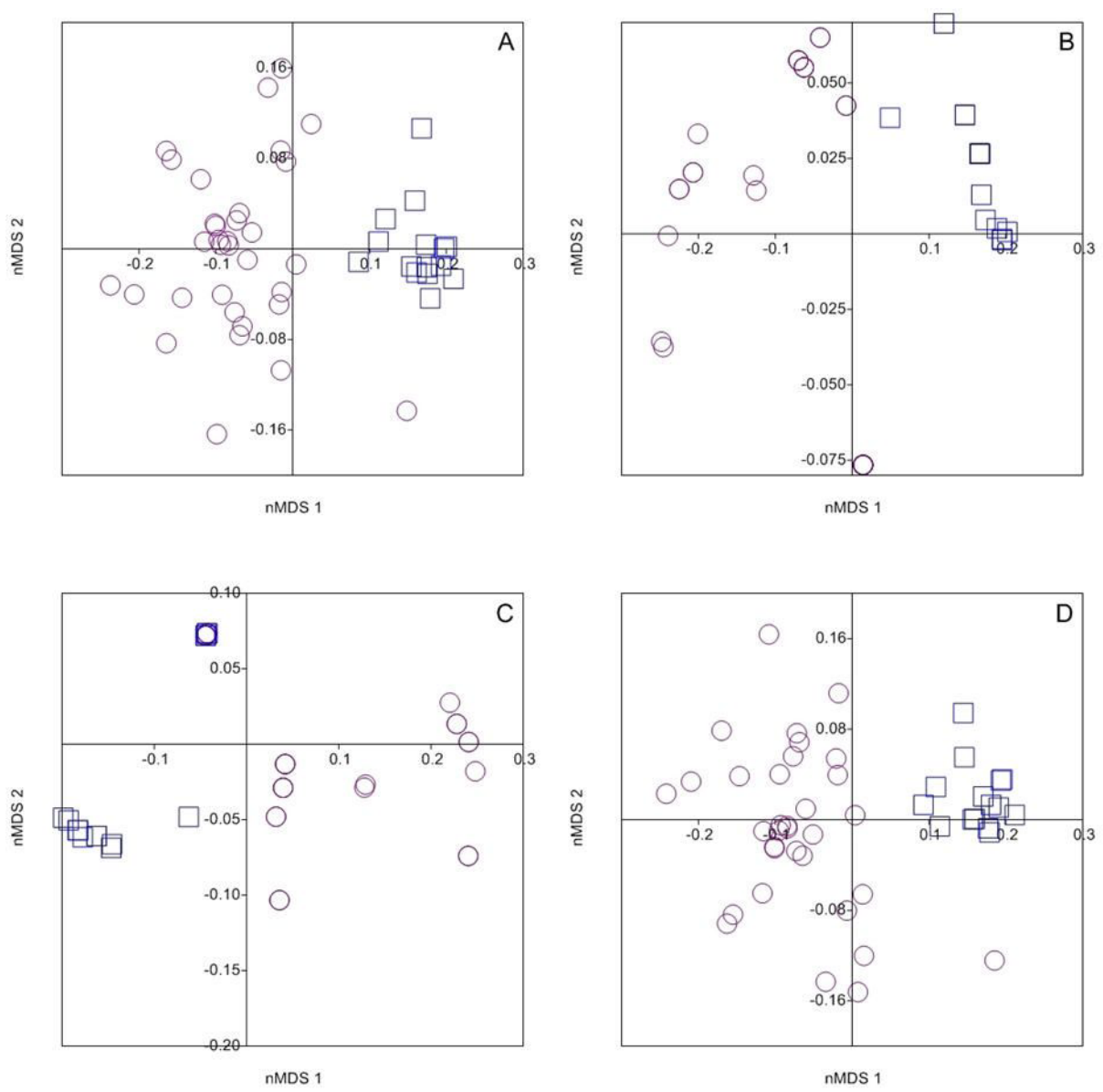

Figure 6. Non-metric multidimensional scaling analysis of diet items origin of P. squamosissimus in preserved area (circle) and impacted area (square). Item sources: animal (A), plant (B), autochthonous (C) and allochthonous (D) in Machado River (Brazilian Amazon), from June 2013 to March 2015. 


\section{Discussion}

In our study, it was clear that P. squamosissimus consumed different food items in preserved and impacted areas. Small pelagic fish (A. bimaculatus) were most commonly found in its diet in the preserved area, while more benthic organisms (P. blochii, H. plecostomus and shrimps) were consumed in the impacted area. Nevertheless, trophic level values for P. squamosissimus were similar in both areas, which could indicate that its feeding plasticity refers to habitat use, varying from pelagic to benthic food chains. This is an opportunistic behavior already identified for this species, in other environments (Bennemann \& Shibatta, 2002). We highlight that the trophic level calculated for P. squamosissimus for both areas analyzed was based on values in the literature (FishBase platform and SeaLifeBase), however it is evident the segregation in the use of food resources by the studied species, based mainly on the composition and volume of the fishes. food items consumed (see Figures 4 and 5).

Large Generalist Predators (LGP) can modify prey-predator interactions, because their bigger body size confer them the ability to feed on a wide variety of prey of different sizes (Woodson et al., 2018). We speculate that behavior responses of P. squamosissimus feeding lower on food chains in both areas evolved because, in higher temperatures, animals have higher relative demand for carbon and digestion of plant tissue is easier, inducing higher rates of herbivory and omnivory (Woodson et al., 2018; Dantas et al., 2019). Generalist and opportunistic species as $P$. squamosissimus are fundamental to restructure impacted food webs, since they could change interactions and trigger trophic cascades on the new environmental conditions (Bartley et al., 2019) despite to remain in the original trophic position.

Since we studied the diet composition of the same generalist species in two contiguous areas, but with different land use, and in the same river, we contend that our gut content analysis was helpful to show the availability of food resources in both areas and the ability of $P$. squamosissimus in changing their diet in the impacted situation, utilizing more benthic material on impacted area in order to maintain a similar trophic position. Therefore, the high abundance of omnivorous fish (P. blochii) and shrimp in gut content of $P$. squamosissimus in impacted areas could be an indicator of degraded aquatic systems, since the omnivorous and detritivorous species use a broad spectrum of food items (Pinto \& Araújo, 2007).
Accordingly, and following these above conditions, differences in gut content analysis and its metrics ( $\mathrm{Fi} \%, \mathrm{Vi} \%$ and $\mathrm{IAi}$ ) could be used as an indicator to evaluate the capacity of modification of the species as well as the environmental conditions.

As already described, the TL values for both areas analyzed were somewhat dissimilar, and this index was calculated using literature values of the trophic level for each diet item. We emphasize that this is a limitation of the present study, considering that the trophic level of each food item consumed by P. squamosissimus was not analyzed in the laboratory, we speculate that such analysis may have resulted in a high variation in the measurement of the trophic level of the P. squamosissimus. However, we observed that this is a common practice in the literature and that the analysis of stomach contents, mainly from carnivorous fish, is quite hampered by the high speed of digestion and deterioration of food items.

The fishermen report a decrease in the abundance and size of the P. squamosissimus specimens, mainly related to the decreasing of the size in the mesh of fishing equipment and the increase in environmental degradation in the Machado River basin. Drenner \& Hambright (2002) describe that predators generally have generalist habits (or omnivorous) and feed on prey in more than one trophic level, potentially spreading the effects of predation throughout the food chain, not focusing on particular trophic levels. As fishing pressure is eased through management efforts to restore overexploited stocks, making it necessary to enter information about interactions between species, especially trophic interactions between prey and predators, in models that promote the prediction and management of recovered fish stocks effectively (Jennings \& Kaiser, 1998). For this, it is necessary to understand the trophic relationships between species and the factors that influence prey-predator interactions.

\section{Acknowledgements}

The authors are grateful to the staff members of Instituto Chico Mendes de Conservação da Biodiversidade (ICMBIO) for their help and assistance during fieldwork. We would like to thank the staff at the Laboratório de Ciências Ambientais of the Universidade Federal de Rondônia for helping us with the identification of stomach contents.

\section{References}

BAKER, R., BUCKLAND, A. and SHEAVES, M. Fish gut content analysis: robust measures of diet composition. Fish and Fisheries, 2014, 15(1), 170 177. http://dx.doi.org/10.1111/faf.12026.

BARROS, L.C., SANTOS, U., ZANUNCIO, J.C. and DERGAM, J.A. Plagioscion squamosissimus (Sciaenidae) and Parachromis managuensis (Cichlidae): A threat to native fishes of the Doce River in Minas Gerais, Brazil. PLoS One, 2012, 7(6), e39138. 
http://dx.doi.org/10.1371/journal.pone.0039138. PMid:22720053.

BARTLEY, T.J., MCCANN, K.S., BIEG, C., CAZELLES, K., GRANADOS, M., GUZZO, M.M., MACDOUGALL, A.S., TUNNEY, T.D. and MCMEANS, B.C. Food web rewiring in a changing world. Nature Research Ecology \& Evolution Community, 2019, 3(3), 345-354. http://dx.doi. org/10.1038/s41559-018-0772-3. PMid:30742106.

BENNEMANN, S.T. and SHIBATTA, O.A. Dinâmica de uma assembleia de peixes do rio Tibagi: a bacia do rio Tibagi. Londrina: Eduel, 2002.

BENNEMANN, S.T., CAPRA, L.G., GALVES, W. and SHIBATTA, O.A. Dinâmica trófica de Plagioscion squamosissimus (Perciformes, Sciaenidae) em trechos de influência da represa Capivara (rios Paranapanema e Tibagi). Iheringia. Série Zoologia, 2006, 96(4), 115-119. http://dx.doi.org/10.1590/ S0073-47212006000100020.

BENNEMANN, S.T., GALVES, W. and CAPRA, L.G. Recursos alimentares utilizados pelos peixes e estrutura trófica de quatro trechos no reservatório Capivara (Rio Paranapanema). Biota Neotropica, 2011, 11(2), 1-7. http://dx.doi.org/10.1590/S167606032011000100006.

BENNEMANN, S.T., SHIBATTA, O.A. and GARAVELlO, J.C. Peixes do rio Tibagi: uma abordagem ecológica. Londrina: Eduel; 2000.

BORNATOWSKI, H., NAVIA, A.F., BRAGA, R.R., ABILHOA, V. and CORREA, M.F.M. Ecological importance of sharks and rays in a structural food web analysis in southern Brazil. ICES Journal of Marine Science, 2014, 7(3), 1586-1592. http:// dx.doi.org/10.1093/icesjms/fsu025.

BRASIL. Ministério do Meio Ambiente-MMA. Reserva biológica do Jaru. Porto Velho: Instituto Chico Mendes de Conservação da Biodiversidade, 2010.

CARVALHO, R.A. and TEJERINA-GARRO, F.L. Environmental and spatial processes: what controls the functional structure of fish assemblages in tropical rivers and headwater streams? Ecology Freshwater Fish, 2015, 24(2), 317-328. http://dx.doi.org/10.1111/ eff. 12152 .

CASATTI, L., TERESA, F.B., GONÇALVES-SOUZA, T., BESSA, E., MANZOTTI, A.R., GONÇALVES, C.D.S. and ZENI, J.D.O. From forests to cattail: how does the riparian zone influence stream fish? Neotropical Ichthyology, 2012, 10(1), 205-214. http:// dx.doi.org/10.1590/S1679-62252012000100020.

CORREA, S.B. and WINEMILLER, K.O. Niche partitioning among frugivorous fishes in response to fluctuating resources in the Amazonian floodplain forest. Ecology, 2014, 95(1), 210-224. http://dx.doi. org/10.1890/13-0393.1. PMid:24649660.

DANTAS, D., CALIMAN, A., GUARIENTO, R., ANGELINI, R., CARNEIRO, L., LIMA, S.,
MARTINEZ, P. and ATTAYDE, J. Climate effects on fish body size-trophic position relationship depend on ecosystem type. Ecography, 2019, 42(9), 1-8. http://dx.doi.org/10.1111/ecog.04307.

DRENNER, R.W. and HAMBRIGHT, R.K.D. Piscivores, trophic cascades, and lake management. The Scientific World Journal, 2002, 2, 284-307. http:// dx.doi.org/10.1100/tsw.2002.138. PMid:12806017.

FERREIRA, A., PAULA, F.R., FERRAZ, S.F.B., GERHARD, P., KASHIWACHI, E.A.L., CYRINO, J.E.P. and MARTINELLI, L.A. Riparian coverage affects diets of characids in Neotropical streams. Ecology Freshwater Fish, 2012, 21(3), 12-22. http:// dx.doi.org/10.1111/j.1600-0633.2011.00518.x.

FREDERICO, R.G., OLDEN, J.D. and ZUANON, J. Climate change sensitivity of threatened, and largely unprotected, Amazonian fishes. Aquatic Conservation, 2016, 26(2), 91-102. http://dx.doi.org/10.1002/ aqc. 2658 .

FROESE, R. and PAULY, D. FishBase [online]. 2019 [viewed 6 June 2019]. Available from: http://www. fishbase.org

GOULDING, M., BARTHEM, R. and FERREIRA, E. The Smithsonian Atlas of the Amazon. Washington: Smithsonian Institution, 2003.

GUBIANI, E.A., GOMES, L.C., AGOSTINHO, A.A and OKADA, E.K. Persistence of fish populations in the upper Paraná River: effects of water regulation by dams. Ecology Freshwater Fish, 2007, 16(3), 191-197. http://dx.doi.org/10.1111/j.16000633.2006.00211.x.

HAHN, N.S., ADRIAN, I.F., FUGI, R. and ALMEIDA, V.L.L. Ecologia trófica. In: A.E.A.M. VAZZOLER, A.A. AGOSTINHO and N.S. HAHN, eds. $A$ planície de inundação do alto rio Paraná: aspectos físicos, biológicos e socioeconômicos. 1. ed. Maringá: EDUEM, 1997, pp. 209-228.

HAHN, N.S., LOUREIRO, V.E. and DELARIVA, R.L. Atividade alimentar de curvina Plagioscion squamosissimus (Heckel, 1840) (Perciformes, Sciaenidae) no rio Paraná. Acta Scientiarum. Biological Sciences, 1999, 21(2), 309-314.

HAMADA, N. and FERREIRA-KEPPLER, R.L. Guia ilustrado de insetos aquáticos e semiaquáticos da Reserva Florestal Ducke. Manaus: Editora da Universidade Federal do Amazonas, 2012.

HAMADA, N., NESSIMIAN, J.L. and QUERINO, R.B. Insetos aquáticos na Amazônia brasileira: taxonomia, biologia e ecologia. Manaus: Editora do INPA, 2014.

HAMMER, O., HARPER, D.A.T. and RYAN, P.D. PAST: paleontological statistics software package for education and data analysis. Paleotolongia Eletronica, 2001, 4(1), 1-9.

HELLAWELL, J.M. and ABEL, R. A rapid volumetric method for the analysis of the food of fishes. Journal 
of Fish Biology, 1971, 3(1), 29-37. http://dx.doi. org/10.1111/j.1095-8649.1971.tb05903.x.

HYSLOP, E.J. Stomach contents analysis - a review of methods and their application. Journal of Fish Biology, 1980, 17(1), 411-429. http://dx.doi. org/10.1111/j.1095-8649.1980.tb02775.x.

INSTITUTO BRASILEIRO DE GEOGRAFIA E ESTATÍSTICA - IBGE. Manual técnico da vegetação brasileira. Rio de Janeiro: IBGE, 1992.

INSTITUTOCHICO MENDES DECONSERVAÇÃO DA BIODIVERSIDADE - ICMBIO. Plano de manejo da reserva biológica do Jaru. Brasília: Instituto de Pesca, 2010.

JENNINGS, S. and KAISER, M.J. The effects of fishing on marine ecosystems. Advances in Marine Biology, 1998, 34, 203-352. http://dx.doi.org/10.1016/ S0065-2881(08)60212-6.

KAWAKAMI, E. and VAZZOLER, G. Método gráfico e estimativa de índice alimentar aplicado no estudo de alimentação de peixes. Boletim do Instituto Oceanográfico, 1980, 29(2), 205-207. http://dx.doi. org/10.1590/S0373-55241980000200043.

KRUSCHE, A.V., BALLESTER, M.V.R., VICTORIA, R.L., BERNARDES, M.C., LEITE, N.K., HANADA, L., VICTORIA, D.C., TOLEDO, A.M., OMETTO, J.P., MOREIRA, M.Z., GOMES, B.M., BOLSON, M.A., GOUVEIA NETO, S., BONELLI, N., DEEGAN, L., NEILL, C., THOMAS, S., AUFDENKAMPE, A.K. and RICHEY, J.E. Efeitos das mudanças do uso da terra na biogeoquímica dos corpos d'água da bacia do rio Ji-Paraná, Rondônia. Acta Amazonica, 2005, 35(2), 197-205. http://dx.doi.org/10.1590/S004459672005000200009 .

LORION, C.M. and KENNEDY, B.P. Relationships between deforestation, riparian forest buffers and benthic macroinvertebrates in neotropical headwater streams. Freshwater Biology, 2009, 54(1), 165-180. http://dx.doi.org/10.1111/j.13652427.2008.02092.x.

LOWE-MCCONNELL, R.H. Estudos ecológicos de comunidades de peixes tropicais. São Paulo: Edusp, 1999.

MANNA, L.R., REZENDE, C.F. and MAZZONI, R. Plasticity in the diet of Astyanax taeniatus in a coastal stream from south-east Brazil. Brazilian Journal of Biology = Revista Brasileira de Biologia, 2012, 72(2), 919-928. http://dx.doi.org/10.1590/S151969842012000500020. PMid:23295523.

MOYLE, P.B.C. and CECH, J.J. Fishes: an introduction to ichthyology. New Jersey: Prentice-Hall, 2004.

NEVES, M.P., DELARIVA, R.L., GUIMARÃES, A.T.B. and SANCHES, P.V. Carnivory during ontogeny of the Plagioscion squamosissimus: a successful non-native fish in a lentic environment of the Upper Paraná River Basin. PLoS One, 2015,
10(1), e0141651. http://dx.doi.org/10.1371/journal. pone.0141651. PMid:26524336.

PAULY, D. and CHRISTENSEN, V. Primary production required to sustain global fisheries. Nature, 1995, 374(6519), 255-257. http://dx.doi. org/10.1038/374255a0.

PINTO, B.C.T. and ARAÚJO, F.G. Assessing of biotic integrity of the fish community in a heavily impacted segment of a tropical river in Brazil. Brazilian Archives of Biology and Technology, 2007, 50(1), 489-502. http://dx.doi.org/10.1590/S151689132007000300015 .

PUSEY, B.J. and ARTHINGTON, A.H. Importance of the riparian zone to the conservation and management of freshwater fish: a review. Marine and Freshwater Research, 2003, 54(2), 1-16. http://dx.doi. org/10.1071/MF02041.

R DEVELOPMENT CORE TEAM. $R$ : a language and environment for statistical computing, version 3.5.2. Vienna: R Foundation for Statistical Computing, 2018 [viewed 1 June 2018]. Available from: http:// www.R-project.org

ROCHA, A.A.F., SANTOS, N.C.L., MEDEIROS, T.N. and SEVERI, W. Relaçôes tróficas entre Acestrorhynchus britskii (nativa) e Plagioscion squamosissimus (introduzida) em sistema de reservatórios em cascata. Boletim do Instituto de Pesca, 2015, 41(3), 917-930.

ROSI-MARSHALL, E.J., VALLIS, K.L., BAXTER, C.V. and DAVIS, J.M. Retesting a prediction of the River Continuum Concept: autochthonous versus allochthonous resources in the diets of invertebrates. Freshwater Science, 2016, 35(2), 534-543. http:// dx.doi.org/10.1086/686302.

SANTOS, G., FERREIRA, E. and ZUANON, J. Peixes comerciais de Manaus. Manaus: Pro-Varzea, 2006.

SANTOS, N.C.L., DO NASCIMENTO, M.T., ROCHA, A.A.F., DIAS, R.M. and SEVERI, W. Uso de recursos alimentares por Plagioscion squamosissimus-piscívoro não-nativo no reservatório de Sobradinho-BA, Brasil. Boletim do Instituto de Pesca, 2016, 40(1), 397-408.

SCHNEIDER, K.N. and WINEMILLER, K.O. Structural complexity of woody debris patches influences fish and macroinvertebrate species richness in a temperate floodplain-river system. Hydrobiologia, 2008, 610(1), 235-244. http://dx.doi.org/10.1007/ s10750-008-9438-5.

SEALIFEBASE [online]. 2018 [viewed 1 June 2018]. Available from: http://sealifebase.org

VAN DER LEE, A.S. and KOOPS, M.A. Are small fishes more sensitive to habitat loss? A generic size-based model. Canadian Journal of Fisheries and Aquatic Sciences, 2015, 72(2), 1-11. http://dx.doi. org/10.1139/cjfas-2015-0026. 
WHITEHOUSE, G.A., BUCKLEY, T.W. and DANIELSON, S.L. Diet compositions and trophic guild structure of the eastern Chukchi Sea demersal fish community. Deep-sea Research. Part II, Topical Studies in Oceanography, 2017, 135(1), 95-110. http://dx.doi.org/10.1016/j.dsr2.2016.03.010.

WOODSON, C.B., SCHRAMSKI, J.R. and JOYE, S.B.A. Unifying theory for top-heavy ecosystem structure in the ocean. Nature Communications, 2018, 9(1), 442-453. http://dx.doi.org/10.1038/ s41467-017-02450-y. PMid:29295998.

WUNDERLICH, A.C., SILVA, R.J., ZICA, E.O., REBELO, M.F., PARENTE, T.E. and VIDALMARTÍNEZ, V.M. The influence of seasonality, fish size and reproductive status on EROD activity in Plagioscion squamosissimus: Implications for biomonitoring of tropical/subtropical reservoirs. Ecological Indicators, 2015, 58(2), 267-276. http:// dx.doi.org/10.1016/j.ecolind.2015.05.063.
ZAR, J.H. Biostatistical analysis. New Jersey: Prentice Hall, 1999.

ZENI, J.O. and CASATTI, L. The influence of habitat homogenization on the trophic structure of fish fauna in tropical streams. Hydrobiologia, 2014, 726(2), 259270. http://dx.doi.org/10.1007/s10750-013-1772-6.

ZENI, J.O., PÉREZ-MAYORGA, M.A., ROAFUENTES, C.A., BREJÂO, G.L. and CASATTI, L. How deforestation drives stream habitat changes and the functional structure of fish assemblages in different tropical regions. Aquatic Conservation, 2019, 38(1), 1-15. http://dx.doi.org/10.1002/ aqc.3128.

Received: 16 September 2019 Accepted: 07 July 2020

Associate Editor: Rafael Marques Almeida. 